\title{
ZUSGS

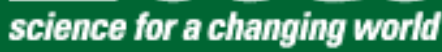 \\ Digital Version of "Open-File Report 92-181: Geologic Map of the Indian Spring Quadrangle, San Bernardino County, California"
}

Geology by

Howard G. Wilshire

Digital Database by

David R. Bedford ${ }^{1}$ and Teresa Coleman

Open-File Report OF 02-272

2002

This report is preliminary and has not been reviewed for conformity with U.S. Geological Survey editorial standards or with the North American Stratigraphic Code. Any use of trade, firm, or product names is for descriptive purposes only and does not imply endorsement by the U.S. Government.

\section{U.S. DEPARTMENT OF THE INTERIOR}

U.S. GEOLOGICAL SURVEY

${ }^{1}$ U.S. Geological Survey, 345 Middlefield Rd. MS-975, Menlo Park, CA 94025. 


\section{Contents}

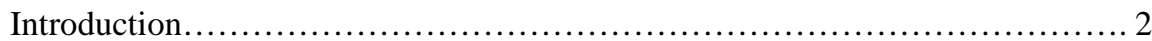

For those who don't use digital geologic map databases ...................... 3

Digital Open-File Contents........................................... 3

Documentation Package....................................... 3

Digital Database Package..................................... 3



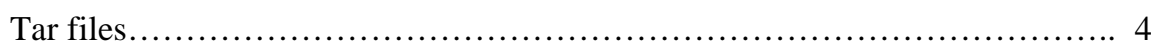

Obtaining the Digital Database and Plotfile Packages........................ 5

Digital Compilation....................................................... 6

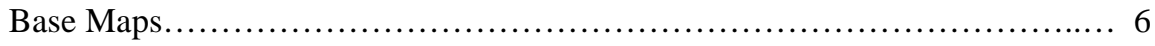

Spatial Resolution................................................. 6

Database Specifics.............................................. 7

Digital Database Format................................... 7

Lines................................................... 7

Areas........................................................ 8



Acknowledgments................................................. 10

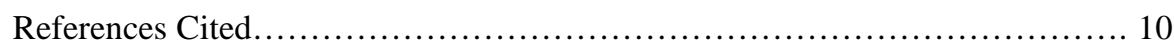



\section{Introduction}

This Open-File Report is a digital geologic map database of a previous paper map Open-File Report. This pamphlet serves to introduce and describe the digital data, as well as a digital version of the original discussion pamphlet. There is no paper map included in the Open-File Report. The report does include, however, PostScript and PDF plot files containing images of the geologic map. For those only interested in a paper plot of information contained in the database or in obtaining the PostScript plot files, please see the section entitled "For Those Who Don't Use Digital Geologic Map Databases" below.

The database delineates map units that are identified by general age and lithology following the stratigraphic nomenclature of the U.S. Geological Survey. The scale of the source maps limits the spatial resolution (scale) of the database to 1:24,000 or smaller. The content and character of the database, as well as three methods of obtaining the database, are described below. 


\section{For those who don't use digital geologic map databases}

For those interested in the geology map area that do not use an ARC/INFO-compatible Geographic Information System (GIS), we have provided two sets of plot files containing images of much of the information in the database. There is a set of images in PostScript format and another in Adobe Acrobat PDF format (see the sections "PostScript plot files" and "PDF plot files" below).

Those interested who have computer capability can access the plot file packages in any of the three ways described below (see the section "Obtaining the digital database and plot file packages"). However, the plot file packages do require gzip and tar utilities to access the plot files. Therefore, additional software, available free on the Internet, may be required to use the plot files (see section "Tar files").

Those without computer capability can obtain plots of the map files through USGS plot-on-demand service for digital geologic maps (see section "Obtaining plots from USGS Open-File Services") or from an outside vendor (see section "Obtaining plots from an outside vendor").

\section{Digital Open-File Contents}

This Open-File Report consists of three digital packages. The first is the Documentation Package, which consists of this file in text, Postscript, and Adobe Portable Document Format (PDF), and FGDC metadata for the report, and a revision list. The second is Digital Database Package, which contains the geologic map database itself, and metadata. The third is the Plotfile Package, which contains an on-screen viewable or printable image of the geologic map created from the database in PostScript and PDF formats.

Note: filenames used in this report are based on combinations of the Open-File Report number, followed by an underscore, followed by the number of the package, followed by an alphabetic character denoting the part of that package, followed by a ".", and a three digit file extension. For example, for a text file for the first part of the documentation package (package number 1) in Open-File Report OF99-999 (a fictitious report number) would have a file name of of99-999_1a.txt

\section{Documentation Package}

The Documentation Package includes descriptions of this report, including instructions on how to get the report, data formats and content. It consists of 3 parts, a text description (this file), FGDC compliant metadata describing the report, and a revision list that lists any revisions made to this report. The documentation package contains the following:

of02-272_1a.txt

of02-272_1a.eps

of02-272_1a.pdf

of02-272_1b.txt

of02-272_1b.html

of02-272_1b2.html

of02-272_1revs.txt a text file of the database description (this file), including the original pamphlet a Postscript file of the database description (this file), including the original pamphlet a PDF file of the database description (this file), including the original report pamphlet a text file of FGDC compliant metadata for this report a HTML file of FGDC compliant metadata for this report a HTML 'FAQ' file of FGDC compliant metadata for this report a text file listing the revisions made to this report

\section{Digital Database Package}

The database package includes geologic map database files for the map area. The digital maps, or coverages, along with their associated INFO directory have been converted to uncompressed ARC/INFO export files for distribution. ARC export files promote ease of data handling, and are usable by some Geographic Information Systems in addition to ARC/INFO (see below for a discussion of working with export files). The ARC export files and associated ARC/INFO coverages, and directories, as well as the additional digital material included in the database, 
are described below:

\begin{tabular}{lll}
$\begin{array}{l}\text { ARC/INFO } \\
\text { export file }\end{array}$ & $\begin{array}{l}\text { Resultant } \\
\text { Coverage }\end{array}$ & \multicolumn{1}{c}{ Description of Coverage } \\
\hline of02-272_2a.e00 & ind-geo & $\begin{array}{l}\text { Faults, depositional contacts, and rock units in the quadrangle, } \\
\text { including annotation for volcanic vents }\end{array}$ \\
of02-272_2b.e00 & ind-smp & $\begin{array}{l}\text { Samples containing K/Ar analysis } \\
\text { Geologic structural measurements }\end{array}$
\end{tabular}

The database package also includes the following files:

of02-272_1b.txt a text file of FGDC compliant metadata for this report

import.aml an ARC/INFO Arc Macro Language file for importing the above coverages

\section{Converting ARC export files}

ARC export files are converted to ARC coverages using the ARC command IMPORT with the option COVER. To ease conversion and maintain naming conventions, we have included an ASCII text file in ARC Macro Language that will convert all of the export files in the database into coverages and create the associated INFO directory. With the Workspace set to the directory containing the Arc Export files, from the ARC command line type:

Arc: \&run import.aml

ARC export files can also be read by some other Geographic Information Systems. Please consult your GIS documentation to see if you can use ARC export files and the procedure to import them.

Note: consult the metadata or the Database Specifics section of this report for details of the format and content of the digital database

\section{Plotfile Package}

For those interested in the geology of map area that don't use an ARC/INFO compatible GIS system we have included a separate data package of printable maps created from the database. Because this release is primarily a digital database, the plot files (and plots derived from) have not been edited to conform to U.S. Geological Survey standards. Small units have not been labeled with leaders and in some instances map features or annotation overlap. The map image is 22 by 32 inches and requires a large plotter to produce paper copies at the intended scale.

The map images were created using a technique that composites the geologic map with the U.S. Geological Survey Digital Raster Graphic (DRG) for the map area, and thus the 'collar' information contained in the DRG is presented on the geologic map.

of02-272_3a.eps $\quad$ A PostScript format file containing an image of the geologic map, at a scale of 1:24000. The size of the map is $22 \times 32$ inch when printed at the map scale.

of02-272_3a.pdf

A PDF format file containing an image of the geologic map, at a scale of 1:24000.

The size of the map is $22 \times 32$ inch when printed at the map scale.

\section{Tar files}

The digital database package described above is stored in a tar (tape archive) file. A tar utility is required to extract the database from the tar file. This utility is included in most UNIX systems, and can be obtained free of charge over the Internet from Internet Literacy's Common Internet File Formats Web page

(http://www.matisse.net/files/formats.html). The tar file may have been compressed with the gzip algorithm, and may be uncompressed with decompression programs, available free of charge over the Internet via links from the USGS Public Domain Software page (http://edcwww.cr.usgs.gov/doc/edchome/ndcdb/public.html). 


\title{
Obtaining the Digital Database and Plotfile Packages
}

The digital data can be obtained in any of three ways:
a. From the USGS Web Pages.
b. Anonymous ftp over the Internet
c. Sending a CDR with request

To obtain tar files of database or plot file packages from the USGS web pages:

The U.S. Geological Survey web site is located at: http://www.usgs.gov/

The primary World Wide Web server for geologic publications of the U.S. Geological Survey in the Western Region is the "Geopubs" server, located at the following URL:

http://geopubs.wr.usgs.gov

The direct URL to the web page for this report is:

http://geopubs.wr.usgs.gov/open-file/of02-272

\section{To obtain tar files of database or plot file packages by ftp:}

The files in these reports are stored on the U.S. Geological Survey Western Region Publications FTP server.

The Internet ftp address of this server is: ftp://geopubs.wr.usgs.gov

The user should log in with the user name anonymous and then input their e-mail address as the password. This will give the user access to all the publications available via ftp from this server.

The files in this report are stored in the subdirectory:

pub/open-file/of02-272

To obtain tar files of database or plot file packages on tape or CDROM:

Database files, PostScript plot files, and related files can be obtained by sending a Recordable compact disk (CDR) or blank tape with request and return address to:

\author{
Indian Spring, California Database \\ c/o Database Coordinator \\ U.S. Geological Survey \\ 345 Middlefield Road, M/S 975 \\ Menlo Park, CA 94025
}

\section{Do not omit any part of this address!}

NOTE: Be sure to include with your request the exact names, as listed above, of the tar files you require. An OpenFile Report number is not sufficient, unless you are requesting both the database package and plot file package for the report.

The compressed tar file will be returned on the compact disk or tape.

\section{Obtaining plots from a commercial vendor}

Many commercial vendors are capable of producing large format plots for a fee. Most commercial vendors will require the plotfiles to be on a CDROM or other portable disk format. Users may download the data from the Internet and create their own CDROM, or we can provide one (See To obtain tar files of database or plot file packages on tape or CDROM). Make sure your vendor is capable of reading compact disks and PostScript plot files, and be certain to provide a copy of this document to your vendor. 


\section{Digital Compilation}

The map from the original publication was scanned at an unknown resolution and vectorized in ARC/INFO. Vectors were edited to faithfully represent the original map. Transformation from scanner to UTM coordinates resulted in an RMS error of .002. Attributes were then assigned to points, lines, and polygons to depict the original map. No positional accuracy information was prescribed to geologic contacts in the original report (such as approximate, concealed, etc), and thus all geologic contacts were attributed as well placed (certain, or solid lines) although the original nature of the contact is unknown. Map units, geologic line types, dip values, and other attribute data were appended with a '?' if the feature was not labeled, or clearly labeled, on the original map. Dip values in the 'dip' field of the structural geology points layer that were not clearly identifiable were calculated as the NEGATIVE assumed value, and annotation values were appended with a '?' (Such as if it is assumed that a dip was 37, but was not clear, -37 was entered into the database, and annotation of 37 ? was created). For instances where the dip value was absent or completely indeterminate, the value '99' was used, and no annotation was created.

The following Quality Control measures were taken: Geologic lines attributed as a 'contact' we checked so as to not separate geologic map units of the same type, except in circumstances where the original map was overly ambiguous. No lines attributed as contacts are 'dangles'. All geologic polygons are attributed with map unit designators found in the original report.

\section{Base Maps}

The base map presented on the geologic map images in this report is the 1:24000 scale U.S. Geological Survey Digital Raster Graphic (DRG) for the map area. DRGs are available from the U.S. Geological Survey, as well as other data providers, and are not distributed with this report. The base map used in the original report may not be the same as that presented in this version.

\section{Spatial Resolution}

Uses of this digital geologic map should not violate the spatial resolution of the data. Although the digital form of the data removes the constraint imposed by the scale of a paper map, the detail and accuracy inherent in map scale are also present in the digital data. The fact that this database was edited at a scale of 1:24,000 means that higher resolution information is not present in the dataset. Plotting at scales larger than 1:24,000 will not yield greater real detail, although it may reveal fine-scale irregularities below the intended resolution of the database. Similarly, where this database is used in combination with other data of higher resolution, the resolution of the combined output will be limited by the lower resolution of these data.

\section{Database Specifics}

\section{Digital database format}

The database in this report was compiled in ARC/INFO, a commercial Geographic Information System (Environmental Systems Research Institute, Redlands, California), with initial work completed with version 3.0 of the menu interface ALACARTE (Fitzgibbon and Wentworth, 1991, Fitzgibbon, 1991, Wentworth and Fitzgibbon, 1991). Final work was done in ARC/INFO version 8.1 PreRelease. The files are in ARC/INFO coverage format, and thus contain vector data. Coverages are distributed in uncompressed ARC export format (ARC/INFO version 8.0.2, and 8.1 PreRelease). ARC/INFO export files (files with the .e00 extension) can be converted into ARC/INFO coverages in ARC/INFO (see the Digital Database Package) and can be read by some other Geographic Information Systems, such as MapInfo via ArcLink and ESRI's ArcView (version 1.0 for Windows 3.1 to 3.11 is available for free from ESRI's web site: http://www.esri.com).

The map databases consist of ARC coverages and supporting INFO files, which are stored in a UTM (Universal Transverse Mercator) projection (Table 1). Digital tics define a 7.5 minute grid of latitude and longitude in the coverages 
Table 1 - Map Projection

The maps are stored in UTM projection

PROJECTION UTM

UNITS METERS $\quad$-on the ground

ZONE $11 \quad-U T M$ zone

DATUM NAD83

PARAMETERS

The content of the geologic database can be described in terms of the lines, points, and the areas that compose the map. Descriptions of the database fields use the terms explained in Table 2.

Table 2 - Field Definition Terms

ITEM NAME name of the database field (item)

WIDTH maximum number of digits or characters stored

OUTPUT output width

TYPE B-binary integer, F-binary floating point number,

I-ASCII integer, C-ASCII character string

N. DEC. $\quad$ number of decimal places maintained for floating point numbers

\section{Lines}

The lines (arcs) are recorded as strings of vectors and are described in the arc attribute table (AAT) described in Table 3. They define the boundaries of the map units, faults, and the map boundaries. These distinctions, including the geologic identities of the unit boundaries, are recorded in the LTYPE field according to the line types listed in Table 4.

Table 3 - Structure of the Arc Attribute Tables

\begin{tabular}{|c|c|c|c|c|c|}
\hline ITEM NAME & WIDTH & OUTPUT & TYPE & N.DEC & Description \\
\hline FNODE\# & 4 & 5 & B & & starting node of arc (from node) \\
\hline TNODE\# & 4 & 5 & B & & ending node of arc (to node) \\
\hline LPOLY\# & 4 & 5 & B & & polygon ID to the left of the arc \\
\hline RPOLY\# & 4 & 5 & B & & polygon ID to the right of the arc \\
\hline LENGTH & 4 & 12 & $\mathrm{~F}$ & 3 & length of arc in meters \\
\hline <coverage>\# & 4 & 5 & B & & unique internal control number \\
\hline$<$ coverage >-ID & 4 & 5 & B & & unique identification number \\
\hline LTYPE & 35 & 35 & $\mathrm{C}$ & & geologic line type (see Table 4) \\
\hline SEL & 1 & 1 & I & & user defined field \\
\hline SYMB & 3 & 3 & I & & user defined field \\
\hline
\end{tabular}

Table 4 - Line Types Recorded in the LTYPE Field of Arc Attribute Tables (listed by coverage name)

ind-geo

Tsd

contact, certain

crest of crater in cinder cone

dike

dike, $\mathrm{Km}$

dike, QTbi

dike, ZYa

fault, approx. located

fault, certain

fault, concealed 
map boundary

s.s. fault, r.l., certain

ind-smp

No Arc Features

ind-str

No Arc Features

\section{Areas}

Map units (polygons) are described in the polygon attribute table (PAT) described in Table 5. The identities of the map units from the original map are recorded in the PTYPE field by map label, listed in Table 6 . Note that ARC/INFO coverages cannot contain both point and polygon information, so only coverages with polygon information will have a polygon attribute table, and these coverages will not have a point attribute table. A complete Description of Map Units is available in the original report, or the digital version of the original report in Appendix 1.

Table 5 - Structure of the Polygon Attribute Tables

ITEM NAME

AREA

PERIMETER

$<$ coverage $>\#$

$<$ coverage>-ID

PTYPE

SEL

SYMB

$\begin{array}{cccc}\text { WIDTH } & \text { OUTPUT TYPE } & \text { N.DEC } \\ 4 & 12 & \text { F } & 3 \\ 4 & 12 & \text { F } & 3 \\ 4 & 5 & \text { B } & \\ 4 & 5 & \text { B } & \\ 35 & 35 & \text { C } & \\ 1 & 1 & \text { I } & \\ 3 & 3 & \text { I } & \end{array}$

Description

area of polygon in map units (meters) length of perimeter in map units (meters) unique internal control number unique identification number map unit label user defined field user defined field

Table 6 - Map Units Recorded in the PTYPE field of Polygon Attribute Tables (listed by coverage name)

$\begin{array}{lllll}\text { ind-geo } & & & \\ \text { CZs } & \text { QTb } & \text { QTf24-2 } & \text { QTf7-1 } & \text { Tsb } \\ \text { Kt } & \text { QTf } & \text { QTf25-1? } & \text { QTf7-2 } & \text { Tsc } \\ \text { Ktm } & \text { QTf1-1 } & \text { QTf25-2? } & \text { QTf7-3 } & \text { Tsd } \\ \text { PD1? } & \text { QTf11-1 } & \text { QTf3-1 } & \text { QTf7-4 } & \text { Tsd? } \\ \text { Q2 } & \text { QTf11-2 } & \text { QTf3-2 } & \text { QTf8-1 } & \text { Tsgn } \\ \text { Q2? } & \text { QTf12-1 } & \text { QTf-3 } & \text { QTf8-2 } & \text { Tsgs } \\ \text { Q2a } & \text { QTf13-1 } & \text { QTf3-3? } & \text { QTf? } & \text { Tsq } \\ \text { Q2b } & \text { QTf16-1 } & \text { QTf32,34 } & \text { QTpb } & \text { Tsv } \\ \text { Q2b? } & \text { QTf17-1 } & \text { QTf4-1 } & \text { QTt } & \text { X1 } \\ \text { Q2c } & \text { QTf17-2 } & \text { QTf4-1? } & \text { QTta } & \text { X2 } \\ \text { Q3-4 } & \text { QTf17? } & \text { QTf4-2 } & \text { QTta? } & \text { Xu } \\ \text { Q3-4? } & \text { QTf2-1 } & \text { QTf4-3 } & \text { QTtb } & \text { Xu? } \\ \text { Q3a } & \text { QTf20-1 } & \text { QTf4-4 } & \text { QTtc } & \\ \text { Q3a? } & \text { QTf20-2? } & \text { QTf5-1 } & \text { Qcp } & \\ \text { Q3b } & \text { QTf20-3 } & \text { QTf64-1 } & \text { TKm } & \\ \text { Q4 } & \text { QTf20-4 } & \text { QTf6A-1 } & \text { Ts } & \text { Ts? } \\ \text { QT1 } & \text { QTf24-1 } & \text { QTf6B-1 } & \text { Ts? }\end{array}$




\section{Points}

Data gathered at a single locality (points) are described in the point attribute table (PAT) described in Table 7 and Table 8. The identities of the points from the original map are recorded in the PTTYPE field by map label (Table 9). For this report there are two point coverages: samples for K/Ar, and structural measurements. Note that ARC/INFO coverages cannot contain both point and polygon information, so only coverages with point information will have a point attribute table, and these coverages will not have a polygon attribute table.

Table 7 - Structure of the Point Attribute Table for Structural measurements

$\begin{array}{lllccl}\text { ITEM NAME } & \text { WIDTH } & \text { OUTPUT } & \text { TYPE } & \text { N.DEC } & \text { Description } \\ \text { AREA } & 4 & 12 & \text { F } & 3 & \text { NA } \\ \text { PERIMETER } & 4 & 12 & \text { F } & 3 & \text { NA } \\ \text { <coverage>\# } & 4 & 5 & \text { B } & & \text { unique internal control number } \\ \text { <coverage>-ID } & 4 & 5 & \text { B } & & \text { unique identification number } \\ \text { PTTYPE } & 35 & 35 & \text { C } & \text { type of structural measurement } \\ \text { DIP } & 3 & 3 & \text { I } & \text { dip of measurement } \\ \text { STRIKE } & 3 & 3 & \text { I } & \text { strike of measurement (right hand rule) } \\ \text { SEL } & 1 & 1 & \text { I } & \text { user defined } \\ \text { SYMB } & 3 & 3 & \text { I } & & \text { user defined }\end{array}$

NOTE: Dip values in the 'dip' field for structural measurements that were not clearly identifiable on the original map were calculated as the NEGATIVE assumed value, and annotation values were appended with a '?' (Such as if it is assumed that a dip was 37 , but was not clear, -37 was entered into the database, and annotation of 37 ? was created). For instances where the dip value was absent or completely indeterminate, the value '99' was used, and no annotation was created.

Table 8 - Structure of the Point Attribute Table for Sample localities.

$\begin{array}{lllccl}\text { ITEM NAME } & \text { WIDTH } & \text { OUTPUT } & \text { TYPE } & \text { N.DEC } & \text { Description } \\ \text { AREA } & 4 & 12 & \text { F } & 3 & \text { NA } \\ \text { PERIMETER } & 4 & 12 & \text { F } & 3 & \text { NA } \\ \text { <coverage>\# } & 4 & 5 & \text { B } & & \text { unique internal control number } \\ \text { <coverage>-ID } & 4 & 5 & \text { B } & & \text { unique identification number } \\ \text { PTTYPE } & 35 & 35 & \text { C } & & \text { type of sample } \\ \text { SAMPNO } & 35 & 35 & \text { C } & & \text { Sample number or identifier } \\ \text { SEL } & 1 & 1 & \text { I } & \text { user defined } \\ \text { SYMB } & 3 & 3 & \text { I } & & \text { user defined }\end{array}$

Table 9 - Content of the PTTYPE field in the Point Attribute Tables for Structural Measurements (listed by coverage name)

ind-str

bedding

foliation

horz bedding

vert foliation and bedding

Table 10 - Content of the PTTYPE field in the Point Attribute Tables for Sample Localities (listed by coverage name) 
ind-smp

sample

\section{Acknowledgments}

The authors wish to thank Stephanie Dudash for her careful review of the digital contents of this Report. David Miller also provided opinions on the accuracy of the reproduction efforts of this report.

\section{References Cited}

Fitzgibbon, T.T., 1991, ALACARTE installation and system manual (version 1.0): U.S. Geological Survey OpenFile Report 91-587B.

Fitzgibbon, T.T., and Wentworth, C.M., 1991, ALACARTE user interface - AML code and demonstration maps (version 1.0): U.S. Geological Survey Open-File Report 91-587A.

Wentworth, C.M., and Fitzgibbon, T.T., 1991, ALACARTE user manual (version 1.0): U.S. Geological Survey Open-File Report 91-587C.

\section{Appendix 1: Original Open-File Report Text}

Note: The original text was scanned and converted to text using Optical Character Recognition technology. The document has been proof read, but conversion errors may exist

\section{U.S. DEPARTMENT OF THE INTERIOR}

\section{U.S. GEOLOGICAL SURVEY}

Geologic Map of the Indian Spring Quadrangle, San Bernardino County, California

by

H.G. Wilshire ${ }^{1}$

Open-File Report 92-181

This report is preliminary and has not been reviewed for conformity with U.S. Geological Survey editorial standards or with the North American Stratigraphic Code. Any use of trade, product, or firm names is for descriptive purposes only and does not imply endorsement by the U.S. Government.

${ }^{1} 345$ Middlefield Road MS/975, Menio Park, CA 94025

\section{GEOLOGIC MAP OF THE INDIAN SPRING QUADRANGLE, SAN BERNARDINO COUNTY, CALIFORNIA \\ INTRODUCTION}


Eruptive rocks of the Cima volcanic field occur almost entirely within six 7.5 minute quadrangles, Indian Spring, Marl Mountains, Granite Spring, Cow Cove, Solomons Knob, and Valley Wells. The following description applies to all six quadrangles.

The Cima volcanic field is a small $\left(-300 \mathrm{~km}^{2}\right)$ Tertiary-Quaternary alkaline basalt field in the Ivanpah highlands (Hewett, 1956), in east-central Mojave Desert (Fig. 1). The basaltic rocks, which range from late Miocene to Holocene, were erupted from at least 71 vents. The younger vents are well-formed cinder cones, whereas older vents are marked by degraded cinder cones, plugs, and crater-fill lava flows.

The volcanic rocks were described in a general geologic study by Hewett (1956). The southern part of the field was mapped by Barca (1966), and the northern part by DeWitt (1980). Topical studies of the volcanic field include the geomorphology of pediment domes (Sharp, 1957; Dohrenwend and others, 1984a,b), geomorphic and soil evolution of the lava flows (Wells and others, 1984; McFadden and others, 1984), paleontology and stratigraphy of Tertiary and Quaternary deposits of the Shadow Valley Basin (Reynolds and Nance, 1988), structural studies (Hewett, 1956; Dunne, 1977; Reynolds, 1990; Skirvin and Wells, 1990), polycyclic volcanism (Renault and Wells, 1990), and evolution of the upper mantle and lower crust beneath Cima based on xenoliths in the basalts (Wilshire, 1990; Wilshire and others, 1991). Mineral resource assessments entailed new geologic mapping in the volcanic field (Greenwood, 1984; Wilshire and others, 1987), and a number of theses have been written on various aspects of the area. The present mapping began as part of a Wilderness Study Area mineral resource assessment, and will be combined with new mapping by R.E. Reynolds in the Solomons Knob and Valley Wells quadrangles, which include the northern part of the Cima volcanic field. Other current studies include isotopic and trace element investigation of the basalts (Farmer and others, 1991), and investigations of detachment faulting (Reynolds, 1990; Davis and others, 1990).

\section{ACKNOWLEDGMENTS}

Thanks are due John Nakata for many new K/Ar dates on the basalts, Doug Prose for assistance in mapping, Brett Cox for thorough and helpful review of the maps and text for the Indian Spring, Marl Mtns., Granite Spring, and Cow Cove quadrangles, Dennis Sorg for sample preparation, and Kathy Nimz for drafting of illustrations.

\section{GEOLOGIC SETTING}

The Cima volcanic field is located near the eastern boundary of the Mojave structural province (Fig. 1), an area thought to be characterized by Quaternary NW-trending strike-slip or dextral faults and Tertiary detachment faults (Dokka, 1983, 1986; Glazner and others, 1989; Skirvin and Wells. 1990;

Brady, 1990; Howard and Miller, 1991).

The volcanic field is underlain by metamorphic and igneous rocks (DeWitt, 1980; Wooden and Miller, 1990), Proterozoic and lower Paleozoic sedimentary rocks (Calzia, 1991), Cretaceous granitic rocks and dikes of the Teutonia batholith (Beckerman and others, 1982), and Miocene terrestrial basin deposits (Reynolds and Nance, 1988). The occurrence of thin septa of Proterozoic rocks in rocks of the Teutonia batholith and the great abundance of dikes of the Cretaceous rocks in adjacent Proterozoic rocks indicate that rocks of the Teutonia batholith lie at shallow depth throughout most of the map area. Gravity data (Wilshire and others, 1987) indicate the presence of rocks of the Teutonia batholith to depths of about $10 \mathrm{~km}$ (R.C. Jachens, oral comm., 1991).

The Miocene basin-fill deposits range from freshwater limestone and fine-grained clastic rocks to extremely coarse fanglomerates, and avalanche deposits; the coarse-grained sediments contain a spectacular array of interspersed landslide blocks composed of Proterozoic, Paleozoic, and Mesozoic rocks derived from outside the area of the volcanic field (Hewett, 1956; Dunne, 1977; Reynolds and Nance, 1988; Wilshire, 1991; Reynolds, 1992). The 18.5 Ma Peach Springs tuff (Nielson and others, 1990) occurs locally in the oldest deposits of the Miocene basins, and 12.8 Ma andesite flows (the $12.8 \mathrm{Ma}$ age is a K/Ar date on a plagioclase separate from altered andesite; a whole rock $\mathrm{K} / \mathrm{Ar}$ date on very fresh pyroxene andesite from the Granite Spring quadrangle yielded an age of $12.1 \mathrm{Ma}$ ) (Table 1) and breccias provide a useful marker higher in the section. The character of deposits in the middle and upper basin fill indicates the presence of steep slopes and active tectonism at the basin margins. Internal unconformities indicate that basin-forming processes and infilling were contemporaneous, as inferred by Nielson and Baratan (1990) and Duebendorfer and Wallin (1991) for Miocene basins along the Colorado River extensional corridor (Howard and John, 1987).

Formation of pediment domes on topographically high areas of the Teutonia batholith probably began 
before eruption of the oldest basalts at about 7.5 Ma (Turrin and others, 1985) as inferred by Sharp (1957), Dohrenwend and others (1984), and Turrin and others (1984) for the Cimacito dome (Fig. 2). Dohrenwend and others (1984b) and current mapping results indicate that at least the Granite Spring, Halloran Wash, Indian Spring, Valley Wells, and Solomons Knob domes (Fig. 2) also predate the basaltic volcanism and are now being exhumed from beneath the coarse Miocene sediments and the younger basalts. Formation of the pediment domes may have begun during development of the older erosion surface recognized in the Halloran Hills by Reynolds (1992); this surface is older than the 18.5 Ma Peach Springs tuff and basal Miocene sediments that lie between the tuff and the erosional surface. Pedimentation is, however, a continuing process, and is now actively affecting exposed parts of all of the domes (Dohrenwend and others, 1984). The Shadow Valley dome (informally named here; Fig. 2) is unique in that its southern part is underlain dominantly by Proterozoic rocks. The Valley Wells dome (informally named here; Fig. 2) has very low relief and is mostly buried beneath Tertiary sedimentary rocks and younger alluvium; the overlapping Tertiary rocks include fine-grained lacustrine clastic rocks such as occur in the deeper parts of the Miocene basins; these rocks are overlain by gravels intercalated with carbonate breccia slide blocks.

Partial (Granite Spring dome) to complete (Halloran Wash dome, and probably also the Valley Wells dome) burial of pediment domes by fine- to coarse-grained Miocene sediments suggests that pedimentation was underway at the time of mid-Miocene sedimentation and doubtless contributed to it. However, the extremely coarse character of much of the mantling sediment, as well as the presence of large gravity slide blocks on the tops of the Squaw Mountain and Solomons Knob domes, indicate that the domes lay within the Miocene basins and most of the Miocene deposits were derived from outside of the present area of the domes, as inferred by Reynolds (1991).

The thickest sections of Miocene deposits occur in the Solomons Knob quadrangle toward the north end and west of the Cima volcanic field, and in the Indian Spring quadrangle south of the southern limits of the volcanic field. The northern section consists of three units: (1) discontinuous basal conglomerate rich in quartzite clasts, lacustrine shale, fine-grained sandstone, limestone, and pyroxene andesite breccia overlying the Peach Springs tuff on the east flank of the Squaw Mountain dome; (2) gravity slide blocks that lie directly on the erosional surface developed on rocks of the Teutonia batholith; and (3) an upper unit of coarse gravel beds intercalated with gravity slide blocks of Paleozoic carbonates, Proterozoic gneisses, and Cretaceous granitic rocks (Reynolds, 1991, 1992). The gravity slide blocks attain dimensions larger than $1.5 \mathrm{~km}$ long and $150 \mathrm{~m}$ thick. Slide blocks deposited directly on rocks of the Teutonia batholith or the basal lacustrine sediments, were then surrounded by coarse gravels and breccias that attain a thickness of as much as $1.5 \mathrm{~km}$ (unless the section is duplicated by undetected faults). Pyroxene andesite flows, considered to be equivalents of the pyroxene andesite breccia to the north, crop out a short distance south of Interstate Highway 15 in the southern part of the Solomons Knob quadrangle and locally in the southern part of the Granite Spring quadrangle, but the Peach Springs Tuff and representatives of the fine-grained lacustrine sediments are only very locally present near Squaw Mountain. Small outcrops of the Peach Springs Tuff without associated lacustrine sediments also occur in the Granite Spring quadrangle. Distinctive oxidized coarse sand and gravel beds belonging to unit (3) occur only north of Interstate Highway 15.

The Miocene section south of Interstate Highway 15 is separable only into Peach Springs tuff, a moderately extensive basal conglomerate rich in clasts of quartzite, probably less than $50 \mathrm{~m}$ thick, and an upper unit of coarse gravel beds and avalanche deposits dominated either by clasts of Proterozoic rocks or of rocks of the Teutonia batholith. Gravity slide blocks of Proterozoic (?) carbonates, quartzite, and gneiss occur only in the southwestern basin deposits in the Indian Spring quadrangle, but no slide blocks of Cretaceous granitic rocks are present. The Miocene basins south of Interstate Highway 15 were apparently not as deep as those to the north so that the basal lacustrine sediments are absent. Quartzite lasts in the basal gravel beds commonly are well rounded and must have been transported substantial distances. They may represent residual deposits formed before the onset of Miocene basin formation; such deposits may have been reworked and concentrated in the initial stages of basin infilling.

The locations of basalts dated by Turrin and others (1984) and new K/Ar dates of basalts and other rocks in the map area are shown on each quadrangle; relevant data are provided in Table 1. Basalts were erupted from about $7.5 \mathrm{Ma}$ to as recently as $60 \pm 30 \mathrm{ka}$ based on whole rock K/Ar dating (Turrin and others, 1984), or about 20 to $30 \mathrm{ka}$ based on the less well-tested method of cosmogenic ${ }^{3} \mathrm{He}$ and ${ }^{21} \mathrm{Ne}$ in varnish on flow surfaces (Wells and others, 1991), or 330 to $400 \mathrm{yr}$ based on ${ }^{14} \mathrm{C}$ of charcoal in the base of flow f2-1, Indian Spring Quadrangle (Katz and Boettcher, 1980); flow f2-1 has been dated by ${ }^{40} \mathrm{Ar} /{ }^{39} \mathrm{Ar}$ at $119 \pm 38 \mathrm{ka}$ by Turrin and Champion (1991). These inferred ages are conflicting ages for the same flow units, or flows whose relative ages are known, and remain to be resolved. There is a well-documented hiatus of eruption between 3 and $1 \mathrm{Ma}$, and an overall difference in composition between older and younger basalts, the older ones being generally hypersthene-normative and younger ones nepheline-normative (Turrin and others, 1985; Wilshire and others, 1991). There is no systematic geographic 
distribution of eruptions with time in the field, except that no volcanic rocks younger than about 4.5 Ma occur in the northern part of the field (north of Interstate Highway 15). Vents within areas of Miocene sediments commonly began with a phreatic (maar) cratering phase, which subsequently was supplanted by cinder and flow eruptions. The common occurrence of multiple flows (2 to 6), some of distinctly different geomorphic age, from the same vent (Turrin and others, 1984), as many as three overlapping craters in the same cinder cone, and several cinder cones within a single maar crater, all point to polycyclic volcanism, rather than a single eruptive episode for each vent, but there is no evidence for a significant time lapse between eruptions. (Reneault and Wells, 1990, infer major time lapses between "polycyclic" eruptions from individual Cima vents, their Crater A and Crater U study sites (Vents 12 and 24-25 of this study) are not appropriately used to assess the time elapsed during polycyclic eruptions, because each of them is composed of two distinctly different vents).

Eruption of the basalts in a setting of active downwasting inferred by Dohrenwend and others (1984) is amply confirmed by this mapping. Evidence cited by Dohrenwend and others (1984) for contemporaneous volcanism and erosion was that active erosion between eruptions not greatly separated in time caused diversion of younger flows around higher older flows. A good example of this are the flows from vents 28 and 29 in the Granite Spring Quadrangle. Additional evidence includes remnants of maar beds at the bottom of a drainage that dissects flow 15-1 in the Marl Mountains Quadrangle. More impressive evidence is found in the southwestern Solomons Knob Quadrangle, where vents 59 and 61-68 formed on the sides and at the bottom of a $150 \mathrm{~m}$ deep canyon cut through slightly older basalt flows.

There is no evident structural control on volcanism in the Cima field. What appear to be essentially contemporaneous vents fall on "alignments" varying by more than $90^{\circ}$. Although it has been suggested that extensional deformation caused the formation of the Miocene basins, and may have continued after filling of the basins (Reynolds, 1990; Davis and others, 1990; Wilshire, 1988), the evidence remains inconclusive.

Evidence of young deformation is seen in the relative uplift of Pliocene lacustrine sediments (Valley Wells quadrangle). These lake beds, which include an ash bed tentatively correlated with the 2.2 Ma Huckleberry Ridge ash, and younger deposits have been uplifted about $60 \mathrm{~m}$ on the east side of the volcanic field (Reynolds, 1990). Other evidence of young tectonism is provided by relative downwarping of the Soda Lake trough on the west side of the volcanic field after 3.9 Ma, as indicated by perched gravel beds (Granite Spring quadrangle) containing clasts of 3.9 m.y. basalt lying $40 \mathrm{~m}$ above active washes (Wilshire, 1991). Several other workers have mapped faults offsetting basalts of Miocene (Hewett, 1956) or younger age (Greenwood, 1984; Skirvin and Wells, 1990), but these have not been confirmed in the present mapping. Tight folds with NE-trending axes occur locally in fine-grained sediments of late Miocene age in the northern part of the Cima field. Such folds could reflect N-S contraction in the Mojave structural province as suggested by Bartley and others (1990), but the exposed structures in the Cima volcanic field are quite small. Moreover, subdomains of compressional deformation in a general setting of extension has been documented by Pettinga (1991).

The broad domal uplifts shown by orientation of foliations in Proterozoic rocks in the Halloran Hills (DeWitt, 1980) do not occur south of Interstate Highway 15. Although foliations in the Proterozoic rocks commonly have shallow dips, they generally have the same direction of dip within continuous outcrops. Irregularities in attitudes of foliations most commonly result from faulting, but in some areas (e.g., the largest outcrops of Proterozoic rocks in the Granite Spring and Cow Cove quadrangles) the foliations are complexly deformed on a scale of meters. Many steep faults, with gouge zones to several meters wide, cut the Proterozoic rocks. A few of these offset Miocene sediments against Proterozoic rocks, and are normal faults or have apparent lateral offsets of no more than a few 10s of meters. Steep zones of intense brecciation and faulting as wide as $300 \mathrm{~m}$ affect Proterozoic rocks in the Indian Spring quadrangle.

\section{GENERAL DESCRIPTION OF UNITS}

\section{Proterozoic and Paleozoic Rocks}

Early Proterozoic rocks of the area were metamorphosed in the Ivanpah orogeny approximately $1.7 \mathrm{Ga}$ (Wooden and Miller, 1990). These rocks are gneisses derived from a variety of protoliths, including sedimentary, plutonic igneous, and volcanic rocks (DeWitt and others, 1984, 1989; Nielson and others, 1987; Wooden and Miller, 1990). Quartzose and pelitic sedimentary protoliths are inferred from highly siliceous gneisses, such as are common in the Seventeen Mile Point area along the southwestern edge of the Indian Spring quadrangle, and from aluminous gneisses common in the southern part of Indian Spring and Marl Mountains quadrangles. Meta volcanic rocks are 
mostly greenstones that likely are intrusives whose age is not known; amphibolites are uncommon. Metaplutonic rocks include mafic gneisses, commonly with well-developed ptygmatic folding of felsic segregations, strongly banded gneisses of intermediate composition, and less common strongly foliated gneisses of granitic composition.

Late Proterozoic and/or lower Paleozoic sedimentary rocks occur locally, and consist of quartzite, quartzite conglomerate, medium-grained white marble, fine-grained weakly metamorphosed limestone and dolomite, and green to black slate. Some of these rocks may represent the Pahrump Group (Hewett, 1966; Dunne, 1977), possibly including members of the Crystal Spring and Kingston Peak Formations (Calzia, 1991). In places the rocks rest unconformably on Early Proterozoic gneisses, and in others are in fault contact with the gneisses. The two occurrences of white marble (one in the Solomons Knob quadrangle north of Interstate Highway 15, the other in the Cow Cove quadrangle) are both in contact with mafic plutonic rocks of the Teutonia batholith; the contacts are parallel to bedding of the marbles. In both occurrences, relatively thin marble beds are interbedded with a dark, quartz-rich gneiss, and in both places sills of the Cretaceous rocks occur among the interbedded marbles and gneisses.

\section{Cretaceous Rocks}

Rocks of the Teutonia batholith (Beckerman and others, 1982) in the Cima area are plutonic representatives of late Mesozoic calcalkaline arc magmatism (Burchfield and Davis, 1981). Ages range from 97 to $90 \mathrm{Ma}$ (DeWitt, and others, 1984). The rocks consist mostly of biotite monzogranite, with less abundant biotite-rich granodiorite, biotite-hornblende quartz diorite, and very felsic granite. The rocks generally are coarse grained, but locally are interleaved with fine grained varieties. They are either nonporphyritic or contain K-feldspar phenocrysts. Quartz diorite and granodiorite, which form the oldest intrusives, are complexly intruded and partially assimilated by the monzogranite. Rocks of intermediate composition commonly have abundant inclusions of quartz diorite and granodiorite. Aplite, pegmatite, and fine-grained granite dikes occur in at least two generations, one emplaced in mafic plutonic rocks, the other emplaced in both mafic and felsic plutonic rocks; crosscutting relations between the two sets occur in the Cow Cove quadrangle. Complex intrusive contacts between rocks of the Teutonia batholith and Proterozoic rocks are well-displayed. In addition to abundant aplite and pegmatite dikes, the waning stages of Cretaceous magmatism are represented by dike swarms that are especially well-displayed in the Granite Spring pediment dome. The dikes range from hornblende/biotite andesite(?) through intermediate dacite (some with distinctive large pink K-feldspar phenocrysts) to rhyolite. Two dikes in the Granite Spring quadrangle yielded K/Ar ages of 88.2 and $90.7 \mathrm{Ma}$ (Table 1). The quartz diorite, granodiorite, and monzogranite host rocks of the dikes commonly are deeply weathered, and, in places, only the continuity of less weathered dikes allows distinction of the plutonic rocks from overlying Miocene and Quaternary sediments.

\section{Cenozoic Rocks}

The oldest known Cenozoic rocks in the Cima volcanic field are middle Miocene sedimentary and volcanic rocks, including the 18.5 Ma Peach Springs Tuff (Nielson and others, 1990). In the northern part of the field, the Peach Springs Tuff nonconformably overlies Teutonia granitic rocks or is locally interbedded with conglomerate, and is itself overlain by freshwater limestones, fine-grained clastic sedimentary rocks, and 12.1 to $12.8 \mathrm{Ma}$ andesitic volcanic rocks. The fine-grained sediments and andesite breccias and flows are unconformably overlain by coarse terrigenous sediments, with locally interspersed fine-grained sediments. Where the Peach Spring Tuff is absent, either lacustrine sediments or coarse Miocene conglomerate overlies Precambrian and Cretaceous rocks in nonconformable depositional contact. The coarse sediments were derived from rocks like those now exposed within pre-Tertiary units of the study area, but also include, and may locally be dominated by, rock types introduced from more distant sources. For example, in the southwestern Indian Spring quadrangle, altered granitic rock is commonly a dominant clast type, but no source of sufficient volume occurs within the map area. A possible source is the Sands granite, which occurs 10-15 km to the west and south. In the northern part of the field, Miocene gravels contain clasts of Paleozoic limestone, Mesozoic sedimentary and volcanic rocks, and Proterozoic syenite. These clasts appear to have their sources in the southern dark Mountains and Mescal Range, some $30 \mathrm{~km}$ to the east (Reynolds and Nance, 1988).

The coarse-grained sediments include debris flows with boulders as much as $10 \mathrm{~m}$ or more across, derived from the Teutonia batholith and Precambrian sources. These deposits are interlayered with finer-grained fluvatile strata and coarse, essentially monolithologic avalanche deposits (Wilshire, 1991). Intercalated with these rocks is a 
great variety of gravity slide blocks, as large as $1.5 \mathrm{~km}$ long. The most conspicuous of these consist of dolomite or limestone breccia, which is resistant to erosion and stands out in the poorly consolidated, easily eroded gravel beds. However, in the Indian Spring and Solomons Knob quadrangles, the slide blocks commonly contain breccias of other metasedimentary, metavolcanic, and Precambrian gneisses, in addition to dolomite, but which are not as well exposed (Dunne, 1977; Wilshire, 1991). In the northern part of the study area, spectacular gravity slide blocks of brecciated Proterozoic and Paleozoic sedimentary rocks, Proterozoic gneisses, and Cretaceous granitic rocks occur (Hewett, 1956; Reynolds and Nance, 1988).

After extensive erosion and bevelling of tilted Miocene sedimentary rocks, alkaline basalt volcanism began in the late Miocene, about 7.5 Ma (Turrin and others, 1985). The oldest rocks form a small group of flows on the west flank of Cima dome in the Marl Mountain quadrangle. The source vents for these flows have not been identified. The old basalt flows are partly buried by younger flows and an associated cinder cone (vent 15). Isolated and clustered vents were active throughout the volcanic field until about $3 \mathrm{Ma}$, when eruptions apparently ceased for about 2 m.y. Numerous vents were active after about $1 \mathrm{Ma}$. This volcanic activity provided a rich variety of landforms, allowing important constraints to be placed on erosion rates of the granitic and metamorphic basement rocks (Dohrenwend and others, 1984), rates of surface modification of the lava flows (Wells and others, 1984), and on rates of pedogenic processes (McFadden and others, 1984). In addition, the volcanic rocks brought to the surface an unusually rich assortment of fragments of lower crustal and upper mantle rocks through which their conduits passed (Wilshire, 1990; Wilshire and others, 1991).

A thin $(7-8 \mathrm{~m})$ section of lacustrine sediments was deposited in the Valley Wells basin between about 2.4 Ma and 0.4 Ma (Reynolds, 1992), which consists of siltstone, claystone, silty peat, and carbonate tufa. A tuff in the lower part of the section may be correlative with the 2.2 Ma Huckleberry Ridge Ash (Reynolds and Jefferson, 1988).

Erosion following initiation of basalt volcanism yielded a variety of fanglomerate deposits, ranging from late Miocene(?) to present. Older deposits generally are deeply dissected so that no original depositional surface remains. Consequently they retain little or no record of soil development. Fragments of caliche generally are important members of surface clast populations. Fans of intermediate age generally have well-developed soils mantled by desert pavements. Pavements may be well-varnished where mafic clast-types are abundant, or only weakly varnished where silicic clast-types are abundant. Soils typically consist of moderately thick $(2-3 \mathrm{~cm})$ vesicular A horizons over argillaceous, and calcic B horizons, with petrocalcic horizons at the base of the profile (Skirvin, 1990). Young deposits commonly have bar-and-swale surface textures except where granitic rocks dominate their source areas, in which case the deposits are bedded arkosic sands with smooth surfaces. Soils are poorly developed or not present. Locally in the eastern Valley Wells and northern Solomons Knob quadrangles, Q1? and Q2 surfaces have a distinctive ribbon texture formed by alignments of shrubs approximately normal to the slope of fan surfaces; the origin of these alignments is not known.

Where basalt flows cap steep scarps, talus deposits of possible Pliocene or Pleistocene age extensively mantle slopes below the flows. Basalt boulders on the slopes are moderately- to well-varnished. In places a platy to laminar petrocalcic horizon (Stage IV or V, Bachman and Machette, 1977) is exposed in avalanche scars; the laminae are parallel to the slope.

\section{REFERENCES}

Bachman, G.O. and Machette, M.N., 1977, Calcic soils and calcretes of the southwestern United States: U.S. Geological Survey Open-File Report 77-794, 163 p.

Barca, R.A., 1966, Geology of the northern part of the Old Dad Mountain quadrangle, San Bernardino County, California: California Division of Mines and Geology, Map 7, scale 1:62,500.

Bartley, J.M., Glazner, A.F., and Schermer, E.R., 1990, North-south contraction of the Mojave block and strike-slip tectonics in southern California: Science, v. 248, p. 1398-1401.

Beckerman, G.M., Robinson, J.P., and Anderson, J.L., 1982, The Teutonia batholith: A large intrusive complex of Jurassic and Cretaceous age in the eastern Mojave Desert, California, in, E.G. Frost and D.L. Martin (eds.), Mesozoic-Cenozoic Tectonic Evolution of the Colorado River Region, California, Arizona, and Nevada: San Diego, California, Cordilleran Publishers, p. 205-221. 
Brady, R.H. Ill, 1990, Stratigraphy and structure at the intersection of the Garlock and Death Valley fault zones, northern Avawatz Mountains, California, in, R.E. Reynolds, S.G. Wells, and R.H. Brady III, At the End of the Mojave: Quaternary Studies in the Eastern Mojave Desert: Redlands, California, San Bernardino County Museum Association, Special Publication, p. 119-128.

Burchfiel, B.C. and Davis, G.A., 1981, Mojave Desert and environs, in, W.G. Ernst (ed.), The Geotectonic Development of California, Rubey Volume 1: Englewood Cliffs, New Jersey, Prentice-Hall, Inc., p. 217252.

Calzia, J.P., 1991, Geology of the Kingston Range, southern Death Valley, California, in, J. Reynolds (ed.). Crossing the Borders: Quaternary Studies in Eastern California and Southwestern Nevada: San Bernardino County Museum Association, 1991 Mojave Desert Quaternary Research Center Symposium, MDQRC 1991, p. 176-188.

Davis, G.A., Burchfiel, B.C., and Parke, M., 1990, Late Miocene detachment fault tectonics in the greater Halloran Hills-Shadow Valley area, eastern San Bernardino County, California: Geological Society of America Abstracts with Program, v. 22, p. 17.

DeWitt, E.H., 1980, Geology and geochronology of the Halloran Hills area, southeastern California, and implications concerning Mesozoic tectonics of the southwestern Cordillera: University Park, Pennsylvania State University, Ph.D. thesis, 269 p.

DeWitt, E.H., Armstrong, R.L., Sutter, J.F., and Zartman, R.E., 1984, U-Th-Pb, Rb-Sr, and Ar-Ar mineral and whole-rock isotopic systematics in a metamorphosed granitic terrain, southern California: Geological Society of America Bulletin, v. 95, p. 723-739.

DeWitt, E.H., Anderson, J.L., Barton, H.N., Jachens, R.C., Podwysocki, M.H., Brickey, D.W., and Close, T.J., 1989, Mineral resources of the South McCullough Mountains Wilderness Study Area, dark County, Nevada: U.S. Geological Survey Bulletin 1730, 24 p.

Dohrenwend, J.C., McFadden, L.D., Turrin, B.D., and Wells, S.G., 1984a, K-Ar dating of the Cima volcanic field, eastern Mojave Desert, California: Late Cenozoic volcanic history and landscape evolution: Geology, v. 12, p. 163-167.

Dohrenwend, J.C., Wells, S.G., Turrin, B.D., and McFadden, L.D., 1984b, Rates and trends of late Cenozoic landscape degradation in the area of the Cima volcanic field, Mojave Desert, California, in, J.C. Dohrenwend (ed.), Surficial Geology of the Eastern Mojave Desert, California: Geological Society of America, 1984 Annual Meeting, Field Trip 14 Guidebook, p. 101- 115.

Dokka, R.K., 1983, Displacements on late Cenozoic strike-slip faults of the central Mojave Desert, California: Geology, v. 11, p. 305-308.

Dokka, R.K., 1986, Patterns and modes of early Miocene crustal extension, central Mojave Desert, California, in, $L$. Mayer (ed.), Extensional Tectonics of the Southwestern United States: A Perspective on Processes and Kinematics: Geological Society of America Special Paper 208, p. 75-95.

Duebendorfer, E.M. and Wallin, E.T., 1991, Basin development and syntectonic sedimentation associated with kinematically coupled strike-slip and detachment faulting, southern Nevada: Geology, v. 19, p. 87-90.

Dunne, G.C., 1977, Geology and structural evolution of Old Dad Mountain, Mojave Desert, California: Geological Society of America Bulletin, v. 88, p. 737-748.

Farmer, G.L., Wilshire, H.G., Wooden, J.L., Glazner, A.F., and Katz, M., 1991, Temporal variations in the sources of alkali basalts at the Cima volcanic field, SE California: Geol. Soc. Amer., Abstracts with Programs, v. 
23, p. 23.

Glazner, A.F., Bartley, J.M., and Walker, J.D., 1989, Magnitude and significance of Miocene crustal extension in the central Mojave Desert, California: Geology, v. 17, p. 50-53.

Greenwood, R.B., 1984, Mineral land classification of the Halloran Spring 15' quadrangle, San Bernardino County, California: California Division of Mines and Geology Open-File Report 84-51 LA.

Hewett, D.F., 1956, Geology and mineral resources of the Ivanpah quadrangle, California and Nevada: U.S. Geological Survey, Professional Paper 275, 172 p.

Howard, K.A. and John, B.E., 1987, Crustal extension along a rooted system of imbricate low-angle faults: Colorado River extensional corridor, California and Arizona, in, M.P. Coward, J.F. Dewey, and P.L. Hancock (eds.). Continental Extensional Tectonics: Geological Society of London, Special Publication No. 28, p. 299-311.

Howard, K.A. and Miller, D.M., 1992, Late Cenozoic faulting at the boundary between the Mojave and Sonoran blocks: Bristol Lake area, California, in, S.M. Richard (ed.). Deformation associated with the Neogene Eastern California Shear Zone, southeastern California and southwestern Arizona: Redlands, California, San Bernardino County Museums Special Publication 92-1, p. 37-47.

Katz, M. and Boettcher, A., 1980, The Cima volcanic field, in, D.L. Fife and A.R. Brown (eds.), Geology and Mineral Wealth of the California Desert: Santa Ana, South Coast Geological Society, p. 236-241.

McFadden, L.D., Wells, S.G., Dohrenwend, J.C., and Turrin, B.D., 1984, Cumulic soils formed in eolian parent materials on flows of the Cima volcanic field, Mojave Desert, California, in, J.C. Dohrenwend (ed.), Surficial Geology of the Eastern Mojave Desert, California: Geological Society of America, 1984 Annual Meeting, Field Trip 14 Guidebook, p. 134-149.

Nielson, J.E. and Baratan, K.K., 1990, Tertiary basin development and tectonic implications, Whipple detachment system, Colorado River extensional corridor, California and Arizona: Journal of Geophysical Research, v. 95, p. 599-614.

Nielson, J.E., Frisken, J.G., Jachens, R.C., and McDonnell, J.R., Jr., 1987, Mineral resources of the Fort Piute Wilderness Study Area, San Bernardino County, California: U.S. Geological Survey Bulletin 1713-C, 12 p.

Nielson, J.E., Lux, D.R., Dalrymple, G.B., and Glazner, A.F., 1990, Age of the Peach Springs Tuff, southeastern California and western Arizona: Journal of Geophysical Research, v. 95, p. 571-580.

Pettinga, J.R., 1991, Structural styles and basin margin evolution adjacent to the San Jacinto fault zone, southern California: Geological Society of America, Abstracts with Programs, v. 23, p. 257.

Renault, C.E. and Wells, S.G., 1990, Geomorphic and pedologic evidence for polycyclic strombolian eruptions in the Cima volcanic field, eastern Mojave Desert, California, in, R.E. Reynolds, S.G. Wells, and R.H. Brady III. At the End of the Mojave: Quaternary Studies in the Eastern Mojave Desert: Redlands, California, San Bernardino County Museum Association, Special Publication, p. 89-99.

Reynolds, R.E., 1990, Erosion, deposition, and detachment: The Halloran Hills sequence, in, R.E. Reynolds, S.G. Wells, and R.H. Brady III (eds.), At The End of the Mojave: Quaternary Studies in the Eastern Mojave Desert: Redlands, California, San Bernardino County Museum Association, Special Publication, p. 101103.

Reynolds, R.E., 1991, The Halloran Hills: A record of extension and uplift, in, Reynolds, J. (ed.), Crossing The Borders: Quaternary Studies In Eastern California And Southwestern Nevada: San Bernardino County 
Museum Association, Special Publication, p. 47-53.

Reynolds, R.E., 1992, Erosion, deposition, and detachment: The Halloran Hills area, California, in, D.R. Sherrod, and J.E. Nielson (eds.). Tertiary Stratigraphy of Highly Extended Terranes, California, Arizona, and Nevada: U.S. Geological Survey Bulletin 2053, p. 21-24

Reynolds, R.E. and Jefferson, G.T., 1988, Timing of deposition and deformation in Pleistocene sediments at Valley Wells, eastern San Bernardino County, California, in, D.L. Weide and M.L. Faber (eds.). This Extended Land: Geological Journeys in the Southern Basin and Range: Geological Society of America, Cordilleran Section Meeting, Las Vegas, Nevada, 1988. Field Trip Guidebook, p. 218-220.

Reynolds, R.E. and Nance, M.A., 1988, Shadow Valley Basin: Late Tertiary deposition and gravity slides from the Mescal Range, in, D.L. Weide and M.L. Faber (eds.), This Extended Land: Geological Journeys in the Southern Basin and Range: Geological Society of America, Cordilleran Section Meeting, Las Vegas, Nevada, 1988, Field Trip Guidebook, p. 207-209.

Sharp, R.P., 1957, Geomorphology of Cima Dome, Mojave Desert, California: Geological Society of America Bulletin, v. 68, p. 273-290.

Skirvin, T.M., 1990, Late Cenozoic geomorphic and structural evolution of the Old Dad Mountain and Cima volcanic field areas, eastern Mojave Desert, California: MSc Thesis, University of New Mexico, 155 p.

Skirvin, T.M. and Wells, S.G., 1990, Late Cenozoic structure, geomorphology, and landscape evolution of the Old Dad Mountain area, California, in, R.E. Reynolds, S.G. Wells, and R.H. Brady III (eds.). At the End of the Mojave: Quaternary Studies in the Eastern Mojave Desert: Redlands, California, San Bernardino County Museum Association, Special Publication, p. 73-88.

Turrin, B.D. and Champion, D.E., $1991,{ }^{40} \mathrm{Ar} /{ }^{39} \mathrm{Ar}$ laser fusion and K-Ar ages from Lathrop Wells, Nevada, and Cima, California: The age of the latest volcanic activity in the Yucca Mountain area: Proc. 2nd Interna't. Conf., High Level Radioactive Waste Management, Las Vegas, Nevada, April 28-May 3, 1991, p. 68-75.

Turrin, B.D., Dohrenwend, J.C., Wells, S.G., and McFadden, L.D., 1984, Geochronology and emptive history of the Cima volcanic field, eastern Mojave Desert, California, in, J.C. Dohrenwend (ed.), Surficial Geology of the Eastern Mojave Desert, California: Geological Society of America, 1984 Annual Meeting, Field Trip 14 Guidebook, p. 88100.

Turrin, B.D., Dohrenwend, J.C., Drake, R.E., and Curtis, G.H., 1985, K-Ar ages from the Cima volcanic field, eastern Mojave Desert, California: Isochron/West, no. 44, p. 9-16.

Wells, S.G., McFadden, L.D., and Olinger, C.T., 1991, Use of cosmogenic 3He \& 21Ne to understand desert pavement formation: Geological Society of America, Abstracts with Programs, v. 23, p. 206.

Wells, S.G., Dohrenwend, J.C., McFadden, L.D., Turrin, B.D., and Mahrer, K.D., 1984, Types and rates of late Cenozoic geomorphic processes on lava flows of the Cima volcanic field, Mojave Desert, in, J.C. Dohrenwend (ed.), Surficial Geology of the Eastern Mojave Desert, California: Geological Society of America, 1984 Annual Meeting, Field Trip 14 Guidebook, p. 116-133.

Wilshire, H.G., 1988, Geology of the Cima volcanic field, San Bernardino County, California, in, D.L. Weide and M.L. Faber (eds.), This Extended Land: Geological Journeys in the Southern Basin and Range: Geological Society of America, Cordilleran Section Meeting, Las Vegas, Nevada, 1988, Field Trip Guidebook, p. 210-213.

Wilshire, H.G., 1990, Lithology and evolution of the crust-mantle boundary region in the southwestern Basin and 
Range province: Journal of Geophysical Research, v. 95, p. 649-665.

Wilshire, H.G., 1991, Miocene basins, Ivanpah highlands area, in, J. Reynolds (ed.), Crossing The Borders: Quaternary Studies in Eastern California And Southwestern Nevada: San Bernardino County Museum Association., Special Publication, p. 54-59.

Wilshire, H.G., Frisken, J.G., Jachens, R.C., Prose, D.V., Rumsey, C.M., and McMahan, A.B., 1987, Mineral resources of the Cinder Cones wilderness study area, San Bernardino County, California: U.S. Geological Survey Bulletin 1712-B, p. B1-B13.

Wilshire, H.G., McGuire, A.V., Noller, J.S., and Turrin, B.D., 1991, Petrology of lower crustal and upper mantle xenoliths from the Cima volcanic field, California: Journal of Petrology, v. 32, p. 169-200.

Wooden, J.L. and Miller, D.M., 1990, Chronologic and isotopic framework for Early Proterozoic crustal evolution in the eastern Mojave Desert region, southeastern California: Journal of Geophysical Research, v. 95, p. 20,133-

20,146 .

Young, R.A. and Brennan, W.J., 1974, Peach Springs tuff: its bearing on structural evolution of the Colorado Plateau and development of Cenozoic drainage in Mohave County, Arizona: Geological Society of America Bulletin, v. 85, p. 83-90.

\section{DESCRIPTION OF MAP UNITS}

Qcp Playa deposits in volcanic craters (Holocene)-Clay and silt of eolian origin redeposited by slope wash on crater floors

Piedmont sedimentary deposits (Holocene to Miocene?)--Light gray to reddish fanglomerate deposits about $1 \mathrm{~m}$ to more than $\mathbf{2 5} \mathrm{m}$ thick; detritus consists of variable proportions of volcanic, plutonic, metamorphic, and sedimentary rocks. The units are subdivided on basis of geomorphic expression and degree of patination of clasts. Divided into:

Q4 Unit 4 (Holocene)--Alluvial fill of active channels: sand, pebbles, cobbles, and boulders affected by modem floods. Channels unvegetated or sparsely occupied by trees and abrasion-tolerant shrubs. No soil development

Q3 Unit 3 (Holocene to Pleistocene)--Undissected to little dissected alluvial deposits of unstratified to weakly stratified sand and gravel. Little or no soil development. Includes colluvial and alluvial veneers 1-3 $\mathrm{m}$ thick on pediment domes formed on granitic rocks of the Teutonia batholith (Fig.2). Locally divided into:

Q3b Subunit 3b-Little dissected deposits about 1 to $2 \mathrm{~m}$ above active channels. Bar-and-swale surface texture where boulders and cobbles present. Clasts unvarnished; little or no soil development. Unstratified to crudely bedded sand and sandy gravel, and boulder lenses. Moderately to well-vegetated by shrubs; where sandy, generally have intershrub lichen cover

Q3a Subunit 3a--Little dissected deposits 1 to $3 \mathrm{~m}$ above active channels. Bar and swale surface texture where boulders and cobbles present. Clasts lightly to moderately varnished; where present, soil horizons include: vesicular A horizon as much as $1.5 \mathrm{~cm}$ thick; nonargillic B horizon; thin carbonate coatings on pebbles. Sparsely to moderately vegetated by shrubs

Q2 Unit 2 (Pleistocene)--Moderately to well dissected alluvial deposits of sand and gravel. Surface pavements well developed, weakly to strongly varnished. Soil horizons moderately to well developed. Locally divided into: 
Q2c Subunit 2c-Moderately dissected alluvial deposits about 1 to $5 \mathrm{~m}$ above adjacent drainages. Moderately dense pavement of pebbles, cobbles, and boulders over a substrate of crudely bedded sand and gravel, with lenticular boulder beds. Surface clasts weakly varnished. Soil horizons include: vesicular A horizon as much as $3 \mathrm{~cm}$ thick, weakly argillic to nonargillic B horizon. Sparsely vegetated by shrubs, local lichen cover

Q2b Subunit 2b-Moderately dissected alluvial deposits about 2 to $6 \mathrm{~m}$ above adjacent drainages. Surface has dense pavement of pebbles, cobbles, and boulders over a substrate of crudely bedded sand and gravel, with lenticular boulder beds; on basalt flows, varnished pavements cover relatively clast-free eolian deposits (McFadden and others, 1984). Surface clasts well-varnished except where dominated by silicic igneous and metamorphic rock types. Soil horizons include: vesicular A horizon as much as $3 \mathrm{~cm}$ thick, argillic B horizon (details of soil horizons given by McFadden and others, 1984). Unvegetated to sparsely vegetated by shrubs

Q2a Subunit 2a-Generally well-dissected alluvial deposits 5 to $10 \mathrm{~m}$ above adjacent drainages, or 1 to $5 \mathrm{~m}$ above adjacent Q2b deposits. Sparsely vegetated by shrubs, diverse vegetation in drainages. Surface has poorly developed pavement of pebbles, cobbles, and boulders, which include caliche, except where weakly dissected. Where present, soil horizons include: vesicular A horizon as thick as $2.5 \mathrm{~cm}$, over argillic B horizon

QTta Talus and colluvial deposits derived from cinder cones and basalt flows (Holocene to early Pliocene) - Pebble, cobble, and boulder veneer on slopes at base of cinder cones and beside eroded flows. Discontinuous aprons of scoria fragments on lower slopes of cinder cones. Petrocalcic horizons below basalt boulder talus attain stage IV to $\mathrm{V}$ and are as thick as $1 \mathrm{~m}$; laminae are parallel to slope, suggesting the talus deposits form stable surfaces as old as several million years. Mapped only where identity or relations of older rocks obscured

QT1 Unit 1 (Pleistocene to Pliocene)--Dissected deposits with no relic pavement, 5 to $10 \mathrm{~m}$ above adjacent drainages. Bouldery surface material with intervening coarse sand and pebbles overlying crudely bedded sand, sandy gravel, and lenticular boulder beds. Surface clasts weakly varnished; generally no soil development

QTs Conglomerate and arkosic sandstone (Quaternary or Pliocene?) - Remnants of fluvial deposits containing clasts of Teutonia granitic rocks and Pliocene basalt, 1-2 m thick, $40 \mathrm{~m}$ above present drainage. Restricted to Granite Spring quadrangle

QT1 Lake deposits of Valley Wells basin (Pleistocene to Pliocene)—Lacustrine and fluviatile siltstone, claystone, silty peat, gravelly sandstone, carbonate tufa, more than $7 \mathrm{~m}$ thick (Reynolds and Jefferson, 1988)

Younger volcanic deposits of the Cima volcanic field (Pleistocene and Pliocene)_Alkaline basalt and hawaiite lava flows and associated pyroclastic rocks. Individual vents numbered sequentially from west to east in strips starting at south end of volcanic field. Divided into:

QTa Coarse ash and lapilli tuff (Pleistocene)—Basalt ash and lapilli deposits, generally less than $1 \mathrm{~m}$ thick; particle sizes dominantly 1-5 mm diameter. Consist of airfall deposits' reworked downslope by rainfall and mass wasting. Restricted to vicinity of vent 13

Unconsolidated tephra deposits (Pleistocene to late Pliocene)—Cinder cone deposits ranging from about 5 to $40 \mathrm{~m}$ thick. Divided into:

QTt Deposits of red oxidized scoria and black unoxidized scoria consisting of pebble to cobble size fragments

QTtb Deposits of blocks and bombs, consisting of boulder-size fragments as much as $5 \mathrm{~m}$ in diameter. Restricted 
to vicinity of vent 13

QTpb Pyroclastic breccia (Pleistocene to late Pliocene)-Consolidated deposits of oxidized scoria and bombs, consisting of pebble to boulder size fragments

QTf Lava flow (Pleistocene to late Pliocene)_Alkaline basalt and hawaiite flows, generally 1-3 $\mathrm{m}$ thick. Contain phenocrysts of olivine, plagioclase, and/or augite in an intersertal or intergranular groundmass of plagioclase, clinopyroxene, olivine, and opaque minerals, with or without glass. Flows are numbered to indicate source vent and sequence of eruption (from 1 to n, oldest to youngest) where known or reasonably inferred (for example, f14-2 is the second flow erupted from vent 14)

QTtc Tuffaceous breccia (Pleistocene to late Miocene)—Deposits of basalt lapilli and bombs, arkosic sand, and blocks of granitic and metamorphic rock, produced by phreatic eruptions in early stage of vent opening. Deposits range up to at least $5 \mathrm{~m}$ thick

Older volcanic deposits of the Cima volcanic field (early Pliocene to late Miocene)_Alkaline basalt and hawaiite lava flows and associated pyroclastic deposits. Discrete cinder cones, clusters of cones, and plugs numbered separately, continuously with Quaternary vent numbers. Divided into:

Tt Tephra (early Pliocene to late Miocene)_Unconsolidated deposits of red oxidized and black unoxidized scoria fragments, pebble to cobble size; about 5-30 m thick

Tpb Pyroclastic breccia (early Pliocene to late Miocene)—Consolidated deposits of red oxidized scoria fragments and bombs, pebble to boulder size; about 1-20 m thick

Tf Lava flow (early Pliocene to late Miocene)-Alkaline basalt and hawaiite lava flows, generally 1-3 m thick- Contain phenocrysts of olivine, plagioclase, and/or augite in an intersertal or intergranular groundmass composed of plagioclase, clinopyroxene, olivine, and opaque minerals, with or without glass

Ta Volcanic rocks (middle Miocene)_Pyroxene andesite lava flows and breccias, 1-3 m thick, interbedded with Ts

Tp Peach Springs Tuff of Young and Brennan (1974) (early Miocene)_Welded crystal-lithic ashflow tuff, 3-5 m thick. Contains adularescent blue sanidine crystals, with biotite, plagioclase, hornblende, quartz, and sphene. Exposed only locally. Age of the Peach Springs Tuff is about 18.5 Ma (Nielson and others, 1990)

Sedimentary rocks (early to middle Miocene)--Fresh water limestone, siltstone, silty claystone, sandstone, gravelly sandstone, conglomerate, breccia, and gravity slide blocks, 1-[ 300+] m thick. Divided into:

Ts Sedimentary rocks-Fine-grained sandstone, siltstone, shale, fresh water limestone locally present near base of deposits. Higher in section poorly consolidated extremely coarse boulder beds (clasts to $10 \mathrm{~m}$ ) are interbedded with monolithologic breccia (avalanche deposits), heterolithologic breccia (avalanche and debris flow deposits), coarse arkosic sandstone, and sandy conglomerate. Interbedded gravity slide blocks as much as $1.5 \mathrm{~km}$ long, 1 to more than $150 \mathrm{~m}$ thick, divided into:

d Dolomite, limestone breccia

c Chert breccia

v Unaltered volcanic rock breccia

gs Greenstone breccia

gr Granitic rock, brecciated and unbrecciated

gn Gneiss, brecciated and unbrecciated

q Interbedded quartzite, shale, and dolomite or limestone, brecciated and unbrecciated 
Tsb Sedimentary rocks - Conglomerate containing a moderate to large proportion of quartzite boulders and cobbles; some clasts consist of crossbedded quartzite, and others of quartzite conglomerate; most are finely bedded quartzite; quartzites are commonly well rounded in contrast to the angularity of clasts of locally derived gneisses

PD1 Limestone (Permian to Devonian)--May include the Permian and Pennsylvanian Bird Spring Formation, sandy and pure limestone; the Mississippian Monte Cristo Limestone, massive pure limestone, locally cherty; and the Devonian Sultan Formation, layered limestone and dolomite

CZs Siliciclastic rocks (Cambrian and Late Proterozoic) - Interbedded limestone and shale in upper part of unit and quartzitic rocks in lower part. May include the Carrara Formation, Zabriskie Quartzite, Wood Canyon Quartzite, and Stirling Quartzite

\section{INTRUSIVE ROCKS}

QTbi Basalt dikes and plugs (Holocene? to late Miocene)--Dikes and plugs of massive basalt emplaced in rocks of Cretaceous to Holocene? age. Dikes typically about $0.5 \mathrm{~m}$ wide

Mafic, intermediate, and felsic dikes (Tertiary? to Cretaceous) - Isolated dikes and swarms of parallel and en echelon dikes in granitic rocks of the Teutonia batholith, and, locally, in Proterozoic rocks. Includes dike-form pseudotachylite of tectonic origin in rocks of Teutonia batholith. Divided into:

TKpt Pseudotachylite (Tertiary? or Cretaceous?)--Forms black, irregular veins from a few $\mathrm{mm}$ to $0.5 \mathrm{~m}$ wide in granitic rocks of the Teutonia batholith; veins of dense flinty rock contain debris of the granitic host rock in various stages of disaggregation. Local fluidal banding. Mapped zone in southeastern Marl Mountains quadrangle is 10 to 20 meters wide, and is exposed over a distance of $1 \mathrm{~km}$. Smaller veins occur in Teutonia rocks south of Marl Springs

TKr Rhyolitic dikes (Tertiary? or Cretaceous?)--Isolated dikes in Proterozoic rocks and granitic rocks of Teutonia batholith. Leucocratic, with sparse feldspar and quartz phenocrysts, in aphanitic groundmass. Locally found within swarms of mafic dikes

TKm Mafic dikes (Tertiary? or Cretaceous?)--Form isolated dikes in Proterozoic rocks and granitic rocks of Teutonia batholith. Melanocratic, with sparse clinopyroxene and altered feldspar phenocrysts in intergranular groundmass of plagioclase laths, greenish biotite, and granular material

$\mathrm{Km} \quad$ Mafic and intermediate dikes (Cretaceous)--Form swarms in rocks of Teutonia batholith; individual dikes generally less than $0.5 \mathrm{~m}$ thick. Includes dark mafic (andesitic?) dikes with abundant zoned hornblende and plagioclase phenocrysts, commonly with biotite; coarser grained varieties have interstitial quartz in groundmass. Also includes light gray dacitic dikes with plagioclase, quartz, and biotite phenocrysts in groundmass of equidimensional feldspars, opaque minerals; some dikes have large pink alkali feldspar phenocrysts. One andesite(?) dike dated at $90.7 \mathrm{Ma}$; Table 1. no.55

Kap Aplite, pegmatite, and fine- to medium-grained biotite monzogranite dikes (Cretaceous)--Isolated dikes in granitic rocks of the Teutonia batholith and in Proterozoic rocks near intrusive contacts with Teutonia granitoids. Two generations of aplite-pegmatite dikes occur as swarms in mafic members of the Teutonia batholith in the northeastern part of Cow Cove quadrangle; the older dikes include fine-grained monzogranite, aplite, and pegmatite, with segregations of vein quartz; in addition to these rock types, the younger dikes also include medium-grained monzogranite, of both felsic and biotite-rich varieties

Teutonia Adamellite of Beckerman and others (1982) (Cretaceous)-Divided into:

Kt Felsic members of Teutonia batholith-White equigranular to porphyritic biotite monzogranite; generally 
medium or coarse grained hypidiomorphic-granular texture; locally contains phenocrysts of pink alkali feldspar. Plagioclase typically shows normal or weak oscillatory zoning. Common weak deformational features include patchy extinction in quartz, kink bands in biotite. Composition ranges to syenogranite and quartz monzonite

Kti Intermediate members of Teutonia batholith-Gray, medium- to coarse-grained, equigranular to porphyritic biotite-rich granodiorite with hypidiomorphic-granular texture; locally contains small phenocrysts of pink alkali feldspar; lath shaped plagioclase has oscillatory zoning. Intermediate in composition between $\mathrm{Kt}$ and $\mathrm{Ktm}$. Common weak deformation shown by kink bands in biotite. Locally contains abundant schlieren rich in biotite and hornblende. Intrudes Ktm, intruded by Kt.

Ktm Mafic member of Teutonia batholith-Melanocratic medium- to coarse-grained, equigranular to porphyritic hornblende/biotite quartz diorite with hypidiomorphic-granular texture; locally contains small pink alkali feldspar phenocrysts; lath-shaped plagioclase has oscillatory zoning. Common weak deformation shown by kink bands in biotite. Forms numerous small enclaves in Kt; more extensive masses in Solomons Knob quadrangle. Complexly intruded and locally partially assimilated by more felsic rocks of the batholith

Zya Alaskite dike (Late Proterozoic? or Middle Proterozoic?)—Form dikes to $5 \mathrm{~m}$ wide in Proterozoic metamorphic rocks; commonly parallel to foliation of host rocks. Medium- to coarse-grained rocks composed of quartz and alkali feldspar; sparse opaque oxides.

\section{METAMORPHIC ROCKS}

\section{Metamorphic rocks (Early Proterozoic)—LLcally divided into:}

X2 Mafic gneiss-Generally strongly foliated biotite and biotite-hornblende gneiss, medium- to coarse-grained, equigranular. Commonly banded, with alternating medium-grained mafic and coarse-grained felsic layers a few $\mathrm{mm}$ to $\mathrm{cm}$ thick. Two subunits contain parallel bands of felsic rock 2-10 $\mathrm{cm}$ thick with spectacular ptygmatic folding; these rocks are most prominent in the Indian Spring and Granite Spring quadrangles

X1 Felsic gneiss-Biotite gneiss, fine to medium grained, equigranular, with mosaic to allotriomorphic-granular texture; includes rocks of granitic composition and very quartz-rich varieties with probable sedimentary protoliths. Commonly finely laminated with alternating felsic and mafic layers a few $\mathrm{mm}$ to a few $\mathrm{cm}$ thick. Layering commonly contorted

$\mathrm{Xu} \quad$ Undivided mafic and felsic gneiss--Complexly interlayered mafic and felsic gneisses of the types subdivided into Pcl and Pc2

Table 1. K-Ar Ages of Cima volcanic rocks, Solomons Knob, Valley Wells, Granite Spring, Cow Cove, Indian Spring, and Marl Mountains quadrangles.

\begin{tabular}{|c|c|c|c|c|c|c|c|}
\hline $\begin{array}{c}\text { Location } \\
\text { No. }\end{array}$ & $\begin{array}{c}\text { Sample } \\
\text { NO. }\end{array}$ & Occurrence & $\begin{array}{c}\mathrm{K} 2 \mathrm{O} \\
(\mathrm{wt} . \%)^{2}\end{array}$ & $\begin{array}{c}{ }^{40} \mathrm{Ar}_{\text {rad }} \\
10^{-11} \mathrm{~mol} / \mathrm{gm}\end{array}$ & $\begin{array}{c}{ }^{\mathrm{Percent}} \\
{ }^{40} \mathrm{Ar}_{\text {rad }}\end{array}$ & $\begin{array}{c}\text { Calculated } \\
\text { Age (Ma) }\end{array}$ & $\begin{array}{c}\text { Assigned } \\
\text { Age (Ma) }\end{array}$ \\
\hline & & & $\begin{array}{c}\text { Solomons } \\
\text { Knob } \\
\text { Quadrangle }\end{array}$ & & & \\
\hline 1 & Ci-60 & flow & $(2.13)$ & 1.191 & 59 & $3.88+-0.04$ & \\
\hline & & & & 1.227 & 67 & $3.99+-0.04$ & $3.94+0.04$ \\
\hline
\end{tabular}




\begin{tabular}{|c|c|c|c|c|c|c|c|}
\hline 2 & Ci-58 & do & $(2.09)$ & 1.140 & 70 & & $3.79+-0.04$ \\
\hline 3 & Ci-57 & do & $(2.13)$ & 1.139 & 55 & $3.71+-0.04$ & \\
\hline & & & & 1.328 & 66 & $4.33+-0.05$ & $4.02+-0.04$ \\
\hline 4 & Ci-74 & do & $(1.99)$ & 1.234 & 49 & $4.71+-0.05$ & \\
\hline & & & & 1.350 & 57 & $4.31+-0.05$ & $4.51+-0.05$ \\
\hline 5 & Ci-76 & do & $(1.97)$ & 1.065 & 64 & & $3.75+-0.06$ \\
\hline 6 & MC3 & do & 1.64 & 1.274 & & & $4.48+-0.15$ \\
\hline 7 & Ci-77 & do & $(1.86)$ & 1.153 & 49 & & $4.31+-0.05$ \\
\hline 8 & Ci-73 & do & $(2.07)$ & 1.195 & 32 & & $4.04+-0.09$ \\
\hline 9 & Ci-78 & do & $(2.03)$ & 1.381 & 61 & & $4.72+-0.06$ \\
\hline 10 & Ci-71 & do & $(1.60)$ & 0.856 & 58 & & $3.71+-0.04$ \\
\hline 11 & Ci-55 & plug & $(2.35)$ & 1.411 & 75 & & $4.17+-0.04$ \\
\hline 12 & Ci-56 & flow & $(2.42)$ & 1.358 & 62 & $3.90+-0.04$ & \\
\hline & & & & 1.448 & 69 & $4.16+-0.04$ & $3.98+-0.04$ \\
\hline 13 & MC5 & do & 1.91 & 1.406 & & & $4.24+-0.17$ \\
\hline 14 & MC5a & do & 1.78 & 1.586 & & & $5.12+-0.16$ \\
\hline 15 & Ci-24 & do & $(0.38)$ & 0.704 & 54 & $12.92+-0.37$ & \\
\hline & & & & 0.694 & 17 & $12.73+-0.62$ & $12.83+-0.50$ \\
\hline & & & & Valley Wells & & & \\
\hline 1 & Ci-25 & flow & $(1.85)$ & 1.215 & 60 & $4.55+-0.09$ & \\
\hline & & & & 1.167 & 46 & $4.37+0.09$ & $4.46+-0.09$ \\
\hline All derangle & & & & & & \\
\hline
\end{tabular}

All determinations are on whole rock samples except Ci-24, which is a plagioclase separate; all samples are basalts except $\mathrm{Ci}-24$, which is andesite

\begin{tabular}{|c|c|c|c|c|c|c|c|}
\hline $\begin{array}{c}\text { Location } \\
\text { No. }\end{array}$ & $\begin{array}{l}\text { Sample } \\
\text { NO. }{ }^{1}\end{array}$ & Occurrence & $\begin{array}{c}\mathrm{K} 2 \mathrm{O} \\
(\text { wt. \% })^{2}\end{array}$ & $\begin{array}{c}{ }^{40} \mathrm{Ar}_{\mathrm{rad}} \\
10^{-11} \mathrm{~mol} / \mathrm{gm}\end{array}$ & $\begin{array}{l}\text { Percent } \\
{ }^{40} \mathrm{Ar}_{\mathrm{rad}}\end{array}$ & $\begin{array}{l}\text { Calculated } \\
\text { Age }(\mathrm{Ma})^{3}\end{array}$ & $\begin{array}{l}\text { Assigned } \\
\text { Age }(\mathrm{Ma})^{3}\end{array}$ \\
\hline & & & & $\begin{array}{c}\text { Granite } \\
\text { Spring } \\
\text { Quadrangle }\end{array}$ & & & \\
\hline 1 & Ci-70 & flow & $(1.85)$ & 1.096 & 69 & & $4.11+-0.05$ \\
\hline 2 & $29-39-1$ & dike & $(2.68)$ & 34.737 & 91 & & $88.19+-0.77$ \\
\hline 3 & MC59 & do & 1.43 & 0.902 & & & $3.64+-0.16$ \\
\hline \multirow[t]{2}{*}{4} & Ci-16 & do & $(2.14)$ & 1.838 & 58 & $5.96+-0.08$ & \\
\hline & & & & 1.912 & 33 & $6.20+-0.09$ & $6.08+-0.12$ \\
\hline \multirow[t]{2}{*}{5} & $\mathrm{Ci}-23$ & do & $(0.76)$ & 10.239 & 52 & $90.76+-1.18$ & \\
\hline & & & & 10.212 & 80 & $90.54+-1.06$ & $90.65+-1.12$ \\
\hline 6 & MC1 & flow & 1.95 & 1.317 & & & \\
\hline \multirow[t]{2}{*}{7} & MC1a & do & 1.43 & 0.96 & & $3.86+-0.12$ & \\
\hline & & & & & & $3.83+-0.12$ & $3.85+-0.12$ \\
\hline 8 & Ci-15 & do & $(1.42)$ & 0.185 & 20 & $0.91+-0.03$ & \\
\hline
\end{tabular}




\begin{tabular}{|c|c|c|c|c|c|c|c|}
\hline & & & & 0.161 & 10 & $0.79+-0.04$ & $0.85+-0.06$ \\
\hline 9 & Ci-14 & do & $(2.28)$ & 0.107 & 2 & $0.33+-0.07$ & \\
\hline & & & & 0.095 & 4 & $0.29+-0.04$ & $0.31+-0.06$ \\
\hline 10 & MC51 & do & 1.53 & 0.07 & & & $0.27+-0.05$ \\
\hline 11 & MC50 & do & 1.4 & 0.184 & & & $0.70+-0.06$ \\
\hline 12 & $25-44-1$ & do & $(4.25)$ & 7.437 & 72 & & $12.11+-0.09$ \\
\hline
\end{tabular}

Sample 29-39-1 is hornblende biotite dacite; Ci-23 is hornblende andesite(?); 25-44-1 is pyroxene andesite; all other samples are basalt All determinations on whole rock samples

\begin{tabular}{|c|c|c|c|c|c|c|c|}
\hline $\begin{array}{c}\text { Location } \\
\text { No. }\end{array}$ & $\begin{array}{l}\text { Sample } \\
\text { NO. }{ }^{1}\end{array}$ & Occurrence & $\begin{array}{c}\mathrm{K} 2 \mathrm{O} \\
(\mathrm{wt} . \%)^{2}\end{array}$ & $\begin{array}{c}{ }^{40} \mathrm{Ar}_{\mathrm{rad}} \\
10^{-11} \mathrm{~mol} / \mathrm{gm}\end{array}$ & $\begin{array}{l}\text { Percent } \\
{ }^{40} \mathrm{Ar}_{\mathrm{rad}}\end{array}$ & $\begin{array}{l}\text { Calculated } \\
\text { Age }(\mathrm{Ma})^{3}\end{array}$ & $\begin{array}{l}\text { Assigned } \\
\text { Age }(\mathrm{Ma})^{3}\end{array}$ \\
\hline & & & & $\begin{array}{c}\text { Cow Cove } \\
\text { Quadrangle }\end{array}$ & & & \\
\hline 1 & MC115 & flow & 1.2 & 0.681 & & & $3.27+-0.13$ \\
\hline 2 & MC4 & do & 1.93 & 0.159 & & & $4.76+-0.17$ \\
\hline \multirow[t]{2}{*}{3} & Ci-9-102 & do & $(2.28)$ & 1.865 & 61 & $5.67+-0.06$ & \\
\hline & & & & 1.777 & 43 & $5.40+-0.07$ & $5.54+-0.07$ \\
\hline \multirow[t]{2}{*}{4} & & bomb & $(2.17)$ & 1.917 & 38 & $6.13+-0.08$ & \\
\hline & & & & 1.972 & 38 & $6.31+-0.08$ & $6.22+-0.08$ \\
\hline \multirow[t]{2}{*}{5} & Ci-10-101 & flow & $(2.35)$ & 1.987 & 37 & $5.86+-0.07$ & \\
\hline & & & & 2.033 & 39 & $6.00+-0.07$ & $5.93+-0.07$ \\
\hline \multirow[t]{2}{*}{6} & $\mathrm{Ci}-12$ & do & $(1.83)$ & 0.825 & 38 & $3.13+-0.04$ & \\
\hline & & & & 0.823 & 41 & $3.12+-0.04$ & $3.13+-0.04$ \\
\hline 7 & MC43 & do & 1.61 & 0.184 & & & $0.32+-0.02$ \\
\hline 8 & MC42 & do & 1.58 & 0.073 & & & $0.27+-0.07$ \\
\hline \multirow[t]{2}{*}{9} & Ci-6-1 & ejected block & $(1.64)$ & 0.071 & 13 & $0.30+-0.02$ & \\
\hline & & & & 0.054 & 10 & $0.23+-0.02$ & $0.27+-0.02$ \\
\hline \multirow[t]{2}{*}{10} & MC41 & flow & 1.6 & 0.074 & & $0.27+0.10$ & \\
\hline & & & & & & $0.26+-0.12$ & $0.27+-0.11$ \\
\hline 11 & MC40 & do & 1.52 & 0.177 & & & $0.67+-0.13$ \\
\hline 12 & MC6 & do & 1.6 & 0.092 & & & $0.33+-0.05$ \\
\hline 13 & MC36 & do & 1.35 & 0.078 & & & $0.33+-0.16$ \\
\hline 14 & MC37 & do & 1.59 & 0.069 & & & $0.25+-0.05$ \\
\hline
\end{tabular}

All determinations on whole rock samples. All samples are basalt

\begin{tabular}{|c|c|c|c|c|c|c|c|}
\hline $\begin{array}{c}\text { Location } \\
\text { No. }\end{array}$ & $\begin{array}{l}\text { Sample } \\
\text { NO. }{ }^{1}\end{array}$ & Occurrence & $\begin{array}{c}\mathrm{K} 2 \mathrm{O} \\
(\mathrm{wt} . \%)^{2}\end{array}$ & $\begin{array}{c}{ }^{40} \mathrm{Ar}_{\mathrm{rad}} \\
10^{-11} \mathrm{~mol} / \mathrm{gm}\end{array}$ & $\begin{array}{l}\text { Percent } \\
{ }^{40} \mathrm{Ar}_{\mathrm{rad}}\end{array}$ & $\begin{array}{l}\text { Calculated } \\
\text { Age }(\mathrm{Ma})^{3}\end{array}$ & $\begin{array}{l}\text { Assigned } \\
\text { Age (Ma) }\end{array}$ \\
\hline & & & & $\begin{array}{c}\text { Indian Spring } \\
\text { Quadrangle }\end{array}$ & & & \\
\hline 1 & MC25 & flow & 1.73 & 0.117 & & & $0.39+-0.08$ \\
\hline 2 & MC24 & do & 1.57 & 0.206 & & & $0.75+-0.22$ \\
\hline
\end{tabular}




\begin{tabular}{|c|c|c|c|c|c|c|c|}
\hline 3 & MC58 & do & 1.91 & 0.052 & & & $0.16+-0.07$ \\
\hline 4 & MC21 & do & 1.56 & 0.171 & & & $0.63+-0.11$ \\
\hline 5 & MC19 & do & 1.54 & 0.341 & & & $0.13+-0.06$ \\
\hline 6 & MC90 & do & 1.58 & 0.038 & & & $0.14+-0.04$ \\
\hline 7 & MC56 & do & 1.52 & 0.045 & & & $0.17+-0.04$ \\
\hline 8 & Sb-4-101 & ejected block & $(1.66)$ & 0.043 & 7 & $0.18+-0.02$ & \\
\hline & & & & 0.036 & 5 & $0.15+-0.02$ & $0.17+-0.02$ \\
\hline 9 & MC75 & flow & 1.5 & 0.057 & & & $0.22+-0.03$ \\
\hline 10 & MC111 & do & 1.56 & 0.127 & & $0.47+-0.05$ & \\
\hline & & & & & & $0.45+-0.04$ & $0.46+-0.05$ \\
\hline 11 & MC76 & do & 1.36 & 0.035 & & & $0.15+-0.06$ \\
\hline 12 & MC20 & do & 1.7 & 0.138 & & & $0.46+-0.08$ \\
\hline 13 & MC70 & do & 1.36 & 0.083 & & & $0.35+-0.04$ \\
\hline 14 & MC26 & do & 1.78 & 0.019 & & & $0.06+-0.03$ \\
\hline 15 & MC66 & do & 1.4 & 0.057 & & & $0.24+-0.04$ \\
\hline 16 & MC121 & do & 1.57 & 0.042 & & & $0.15+-0.04$ \\
\hline 17 & MC13 & do & 1.61 & 0.046 & & & $0.17+-0.06$ \\
\hline 18 & MC14 & do & 1.76 & 0.052 & & $0.16+-0.04$ & \\
\hline & & & & & & $0.17+-0.04$ & $0.17+-0.04$ \\
\hline 19 & MC12 & do & 1.46 & 0.147 & & & $0.58+-0.16$ \\
\hline 20 & MC16 & do & 1.43 & 0.077 & & & $0.32+-0.09$ \\
\hline 21 & MC123 & do & 1.64 & 0.145 & & & $0.51+-0.04$ \\
\hline 22 & MC86 & do & 1.54 & 0.034 & & & $0.13+-0.03$ \\
\hline 23 & MC85 & do & 1.56 & 0.024 & & & $0.09+-0.07$ \\
\hline 24 & MC1 & do & 1.95 & 1.317 & & & $3.88+-0.09$ \\
\hline Al def & & & & & \\
\hline
\end{tabular}

All determinations on whole rock samples. All samples are basalt

\begin{tabular}{|c|c|c|c|c|c|c|c|}
\hline $\begin{array}{c}\text { Location } \\
\text { No. }\end{array}$ & $\begin{array}{l}\text { Sample } \\
\text { NO. }{ }^{1}\end{array}$ & Occurrence & $\begin{array}{c}\mathrm{K} 2 \mathrm{O} \\
(\text { wt. } \%)^{2}\end{array}$ & $\begin{array}{c}{ }^{40} \mathrm{Ar}_{\mathrm{rad}} \\
10^{-11} \mathrm{~mol} / \mathrm{gm}\end{array}$ & $\begin{array}{l}\text { Percent } \\
{ }^{40} \mathrm{Ar}_{\mathrm{rad}}\end{array}$ & $\begin{array}{l}\text { Calculated } \\
\text { Age }(\mathrm{Ma})^{3}\end{array}$ & $\begin{array}{c}\text { Assigned } \\
\text { Age }(\mathrm{Ma})^{3}\end{array}$ \\
\hline & & & & $\begin{array}{c}\text { Marl } \\
\text { Mountains } \\
\text { Quadrangle }\end{array}$ & & & \\
\hline 1 & MC100 & flow & 1.26 & 0.239 & & & $1.09+-0.08$ \\
\hline 2 & MC61 & do & 1.43 & 0.147 & & & $0.59+-0.12$ \\
\hline \multirow[t]{2}{*}{3} & Ki-5-101 & ejected block & $(1.58)$ & 0.109 & 18.1 & $0.48+0.02$ & \\
\hline & & & & 0.12 & 22.7 & $0.53+0.02$ & $0.51+-0.03$ \\
\hline 4 & MC55 & flow & 1.59 & 0.193 & & & $0.70+-0.06$ \\
\hline 5 & MC88 & do & 1.3 & 0.074 & & & $0.33+-0.04$ \\
\hline 6 & Ci-2-101 & ejected block & $(1.86)$ & 0.016 & 3 & $0.06+-0.02$ & \\
\hline
\end{tabular}




\begin{tabular}{|c|c|c|c|c|c|c|c|}
\hline & & & & 0.018 & 3 & $0.07+-0.02$ & $0.07+-0.02$ \\
\hline 7 & MC2 & flow & 1.66 & 1.861 & & & $6.47+-0.18$ \\
\hline 8 & MC2a & do & 1.17 & 1.54 & & & $7.55+-0.17$ \\
\hline 9 & MC91c & do & 1.67 & 2.011 & & & $6.92+-0.32$ \\
\hline 10 & MC62 & do & 1.4 & 0.207 & & & $0.85+-0.05$ \\
\hline 11 & Ci-1-101 & do & $(1.99)$ & 0.098 & 25 & & $0.34+-0.01$ \\
\hline 12 & MC87 & do & 1.64 & 0.144 & & & $0.50+-0.03$ \\
\hline 13 & MC124 & do & 1.31 & 0.258 & & & $1.14+-0.12$ \\
\hline 14 & MC28 & do & 1.68 & 0.097 & & & $0.33+-0.03$ \\
\hline 15 & MC29 & do & 1.4 & 0.184 & & & $0.70+-0.06$ \\
\hline
\end{tabular}

All determinations on whole rock samples. All samples are basalt

${ }^{1} \mathrm{MC}$ numbers are data from Turrin et al (1985)

${ }^{2}$ For multiple determinations, value in parentheses is arithmetic mean used in age calculation

${ }^{3} \mathrm{~K}-\mathrm{Ar}$ ages were calculated using the constants for the radioactive decay and abundance of $40 \mathrm{~K}$ recommended by the International Union of Geological Sciences Subcommission on Geochronology (Steiger and Jager, 1977). These constants are:

$$
?_{\mathrm{e}}=0.5801 \times 10^{-10} \mathrm{yr}^{-1}, ?_{\mathrm{B}}=4.962 \times 10^{-10} \mathrm{yr}^{-1} \text {, and }{ }^{40} \mathrm{~K} / \mathrm{K}_{\mathrm{total}}=1.167 \times 10^{-4} \mathrm{~mol} / \mathrm{mol} \text {. }
$$

References:

Steiger, R.H., and Jager, E., 1977, Subcommission on geochronology: Convention on the use of decay constants in geo and cosmochronology, Earth and Planetary Science Letters, v. 36, no. 3, p. 359-362

Turrin, B.D., Dohrenwend, J.C., Drake, R.E., and Curtis, G.H., 1985, K-Ar ages from the Cima volcanic field, Eastern Mojave Desert, California: Isochron/West, no. 44, p. 9-16. 